\title{
Alain Badious Paulus-læsning
}

\author{
Ph.d.-stipendiat, cand. theol. Mads Peter Karlsen
}

\begin{abstract}
In philosophical and theological circles there has been a tendency to read Alain Badiou's book Saint Paul - La fondation de l'universalisme as part of a more widespread 'return to religion' in the field of philosophy. This article argues that if we read Badiou's book in this context we risk a serious misunderstanding of the relationship between philosophy and religion and religion and politics in Badiou's work. The argument proceeds in two stages. Firstly, by examining Badiou's 'formalistic' approach to Paul, a more general view of the relation between philosophy and religion is uncovered in his work. Secondly, the subsequent discussion aims to illustrate how we can understand Badiou's claim in Saint Paul that his intention in the book 'is neither historicizing nor exegetical, but subjective through and through'. This 'subjective intention' is illuminated through a survey of three more or less coherent issues in Badiou's book, summarized under the following headings: Badiou's Paul as a 'literary instantiation', a 'philosophical intervention' and a 'political inspiration'. At the heart of all three issues is the same concern, namely a concern for a specific conception of truth, which Badiou believes can be found in Paul.
\end{abstract}

Key words: Alain Badiou - Paul - the 'return to religion' - philosophy and religion - religion and politics - concept of truth - formalism - hermeneutics.

\section{Indledning}

I 1997 udgav Alain Badiou, professor ved Ecole Normale Supérieure i Paris, politisk aktivist på den yderste venstrefløj og en af Frankrigs mest originale nulevende filosoffer, en lille bog med titlen Saint Paul - La fondation de l'universalisme. ${ }^{1}$ Badiou er en forholdsvis ukendt skikkelse i en dansk sammenhæng, men oversættelsen af to af hans bøger inden for de seneste par år kunne tyde på, at det måske er ved at ændre sig. ${ }^{2}$ Bogen om Paulus, der var en af de første af Badious bø-

1. Alain Badiou, Saint Paul - La fondation de l'universalisme (Paris: PUF 1997) (herefter SP).

2. Alain Badiou, Etikken - Et essay om erkendelsen af det onde (Århus: Philosophia 2007); Alain Badiou, Grundrids af metapolitikken (Århus: Forlaget Slagmark 2007). 
ger, som blev oversat til engelsk, er også en af hans bedst sælgende bøger og har i høj grad været medvirkende til, at han i dag er genstand for en hastigt voksende reception langt ud over Frankrigs grænser. Badious bog blev samtidig startskuddet for en tiltagende interesse for Paulus, og for kristen teologi mere generelt, blandt flere andre af samtidens væsentlige filosoffer. En interesse, der i sig selv måske nok er opsigtvækkende, men som bestemt ikke bliver mindre opsigtsvækkende af, at de fleste af disse filosoffer er erklærede marxister eller ateister, eller som Badiou selv, ligefrem begge dele. Denne bemærkelsesværdige og stadig voksende filosofiske interesse for Paulus har da også efterfølgende sat sig tydelige spor i det teologiske landskab, bl.a. i form af en række konferencer og bogudgivelser.

Måske grundet denne særlige kontekst er der såvel i filosofiske som teologiske kredse en vis tendens til at læse Badious bog om Paulus som en del af en mere overgribende 'vending' imod eller tilbage til religion og teologi inden for filosofien. Denne vending er, som det fremgår af litteraturen om den, ${ }^{3}$ et komplekst fænomen med repræsentanter for meget forskellige filosofiske traditioner. Den kommer dog samtidig også til udtryk i en række mere generelle tendenser, der groft sagt kan opremses som tre forskellige, men ligeledes delvist overlappende positioner. For det første er der en position, der med afsæt $i$ en erkendelsesteoretisk dekonstruktion af en absolut modsætning mellem tro og viden, religion og fornuft, plæderer for en 'postmetafysisk' tilnærmelse af filosofi og teologi (Jacques Derrida, John D. Caputo). For det andet er der en position, der med udgangspunkt i de vanskeligheder, som den rent naturvidenskabelige og rationalistiske tilgang synes at have ved at løse mange af samtidens menneskeskabte problemer, plæderer for tesen om et 'post-sekulært' samfund, der anerkender og forsøger at drage fordel af religionens moralske ressourcer og sociale mobiliseringskraft (Jürgen Habermas, Charles Taylor). For det tredje er der en position, der i forlængelse af murens fald og indvarslingen af en såkaldt 'post-ideologisk' tidsalder, har afsøgt potentialer til at revitalisere en marxistisk eller antikapitalistisk orienteret politik især i dele af den kristne teologiske tradition (Slavoj Žižek, Giorgio Agamben). Blandt de mere overordnede anliggender eller tematikker, som karakteriserer denne vending, synes således at

3. Den teologiske vending i filosofien har bl.a. været diskuteret i: Niels Grønkjær (ed.), Return of God: Theological Perspectives in Contemporary Philosophy, Odense (University Press of Southern Denmark 1998); Hent de Vries, Philosophy and the Turn to Religion, (Baltimore: John Hopkins University press 1999); Dominique Janicaud (ed.), Phenomenology and the "Theological Turn", (New York: Fordham University Press 2000); Jayne Svenungsson, Guds aterkomst: en studie av gudsbegreppet inom postmodern filosofi (Göteborg: Glänta produktion 2007). 
være de tre følgende. For det første en diskussion om forholdet mellem filosofi og teologi. For det andet en problematisering af dikotomien mellem det sekulære og det religiøse. For det tredje er der en fornyet filosofisk interesse for relationen mellem religion og politik.

I det følgende vil jeg anskueliggøre, hvorfor jeg mener, at vi imidlertid risikerer at ende $\mathrm{i}$ en alvorlig misforståelse, ikke alene af Badious bog om Paulus, men også mere generelt af hans position i forhold til de just skitserede tematikker, hvis vi læser den inden for rammerne af og som led i denne 'vending' imod religion. Badiou, der i øvrigt aldrig har beskæftiget sig særlig eksplicit med religiøse eller teologiske emner, har da også selv ytret sig kritisk i forhold til receptionen af hans værk, netop når det angår spørgsmålet om religion. ${ }^{4} \mathrm{Jeg}$ foreslår således, at vi i stedet som udgangspunkt for vores læsning af Saint Paul tager Badiou på ordet, når han på bogens allerførste side understreger, at "I grunden har jeg aldrig rigtig forbundet Paulus med religion." 5 Det centrale spørgsmål, som jeg vil se nærmere på i det følgende, bliver derfor også: Hvis det ikke er religion, hvad er det så Badiou forbinder Paulus med? Eller lidt anderledes accentueret: Hvad er det ved apostelen Paulus, som gør, at filosoffen Badiou finder det værd at beskæftige sig med ham? Belysningen af dette spørgsmål vil, som vi skal se, samtidig åbne muligheden for en nærmere afklaring af Badious position i forhold til de ovennævnte problemstillinger vedrørende forholdet mellem filosofi og religion og mellem religion og politik.

\section{Formalisering kontra hermeneutik}

Badiou har skrevet indgående om centrale litterære skikkelser som Stephane Mallarmé, Arthur Rimbaud og Samuel Beckett, ${ }^{6}$ men han har til forskel fra flere af sine samtidige ligeledes litteraturinteresserede kollegaer, som fx Michel Foucault og Jacques Derrida, aldrig været synderlig optaget af sprogfilosofiske problemer. Mens Badiou i sin læsning af filosofiens kanoniske værker og litteraturens klassikere gør sig masser af betragtninger om den metode og de stilistiske træk, der kendetegner den forfatter, han behandler, så finder man til gengæld

4. Se Alain Badiou, "Universal truth and the Question of religion - an interview with Alain Badiou", Journal of Philosophy and Scripture 3:1 (2005), 38-42, 40 (herefter UT).

5. SP, 1. Hvor intet andet fremgår, er de franske oversættelser mine egne.

6. Se Alain Badiou, Conditions (Paris: Seuil 1992) (herefter C) kapitel 5, 6 og 15; Alain Badiou, Petit manual d'inesthetique (Paris: Seuil 1998) kapitel 5 og 9; Alain Badiou, Beckett: L'increvable desir (Paris: Hachette 1995). 
stort set ingen generelle hermeneutiske eller litteraturteoretiske refleksioner, heller ikke over hans egen metode. Bogen om Paulus er i den henseende ingen undtagelse. Når det alligevel er værd at gøre sig et par enkelte overvejelser over Badious uudtalte fremgangsmåde $\mathrm{i}$ bogen, skyldes det, at metode-problematikken på en instruktiv vis foregriber et af de spørgsmål, der står i centrum for det følgende, nemlig spørgsmålet om forholdet mellem religion og filosofi.

Hvad angår refleksioner over sin tilgang, så begrænser Badiou sig $\mathrm{i}$ Saint Paul til ret kortfattet i bogens prolog at fastslå, at han ikke læser Paulus' breve som hellige tekster, men i stedet læser dem "på samme måde som man vender tilbage til de klassiske tekster, man er særligt bekendt med; deres stier er veltrådte; deres detaljer ophævet; deres kraft bevaret."7 Med hans betegnelse af Paulus' tekster som 'klassiske' kunne man måske umiddelbart tro, at det, Badiou her taler for, er en hermeneutisk tilgang i stil med eksempelvis den, man finder hos Hans-Georg Gadamer, som jo netop opererer med et begreb om det klassiske værk, kendetegnet ved dets 'varige kraft' i form af et i princippet ubegrænset fortolkningspotentiale. ${ }^{8}$ Men det gør han bestemt ikke. Tværtimod, Badiou afviser eksplicit, at hans læsning af Paulus skulle være hermeneutisk. Som han selv understreger, består hans anliggende ikke i at afdække en skjult betydning i Paulus' tekster. ${ }^{9}$ Faktisk kan Badious uekspliciterede tilgang i Saint Paul bedst beskrives som et opgør med og en kontrast til hermeneutikken. Om han så yder hermeneutikken retfærdighed, er en anden sag.

Formalisering kan som udgangspunkt bredt formuleret siges at være den proces, hvorigennem en relativt uformel praksis eller et tankesæt sættes på en formel. Paradigmatisk er naturligvis matematikkens formalisering i aksiomer, som for eksempel i Euklids Elementer. Badiou anvender imidlertid også ordet $\mathrm{i}$ en noget bredere forstand, for eksempel i bogen Le Siècle, hvor han udover det 20. århundredes formaliseringer i matematikken, ligeledes beskriver nye såvel kunstneriske (avantgardismen) som politiske (leninismen) praksisser i det 20. århundrede som formaliseringer af disse områder. Det væsentlige i denne sammenhæng er, at for Badiou handler en formalistisk tilgang, i modsætning til en hermeneutisk tilgang, ikke om at forstå eller fortolke; den handler tværtimod snarere om at umuliggøre fortolkning. Som Badiou understreger i Le Siècle: "Hvis et værk skal fortolkes, kan fortolkes, er det fordi der resterer for meget partikularitet, fordi det ikke har nået handlingens rene transparens, fordi det ikke har blot-

7. SP, 2. Se også UT, 38.

8. Hans-Georg Gadamer, Sandhed og Metode: Grundtrak af en filosofisk hermeneutik (Århus: Systime Academic 2004), 276.

9. UT, 38. 
lagt dets reelle." 10 Det skal understreges, at det 'reelle' her ikke skal tages i betydningen 'virkelighed'. Tværtimod modstiller Badiou disse to begreber på en sådan måde, at 'virkeligheden', stik imod i ordets gængse betydning, for Badiou snarere har karakter af ideologi, i den forstand at: "Det er virkeligheden [la réalité] der forhindrer afdækningen af det reelle [le réel] som ren overflade." 11 Virkeligheden indebærer i modsætning til det reelles rene overflade en dybde, idet den forudsættes at rumme noget, et indhold, som kalder på at blive repræsenteret og fortolket, kort sagt på en hermeneutik. I kontrast hertil understreger Badious derimod, "[...] at adgangen til det reelle opnås gennem formen [...]."12 Mens hermeneutikken altid søger at fortolke et indhold, så består den formalistiske tilgang derimod i at evakuere eller 'subtrahere' - og dermed udelukke fortolkning af ethvert indhold. Formalisering indstifter således i kraft af sin indifference over for indholdet en distance til virkeligheden, der gør det muligt at bryde med dens ideologiske repræsentationer og nå frem til eller træffe på det reelle. Det skal imidlertid understreges, at dette ikke er et spørgsmål om at isolere formen fra indholdet; formalisering består ikke i at repræsentere det reelle i form af ren form. Det reelle "[...] er ikke indfanget $i$ formen, det transiterer gennem formen." 13

10. Alain Badiou, Le Siècle (Paris: Seuil 2005), 227-228 (herefter LS).

11. LS, 98. Badious brug af begrebet om 'det reelle' er stærkt inspireret af Lacan. En inspiration, som Badiou har uddybet således: "What especially interested me about Lacan was his conception of the real. First, the distinction he makes between the real and reality, which is not the same as the classical metaphysical distinction between appearance and reality, or between phenomenon and noumenon. And in particular, this conception of the real as being, in a situation, in any given symbolic field, the point of impasse, or the point of impossibility, which precisely allows us to think the situation as a whole according to the real", Alain Badiou: "Politics and Philosophy - An interview with Alain Badiou", Angelaki: Journal of Theoretical Humanities 3:3 (1998),113-133,124. Det reelle er altså ikke virkeligheden, men snarere det, der på én og samme tid konstituerer og unddrager sig virkelighedens repræsentation. Mens både Lacan og Badiou altså forstår det reelle som et 'dødt punkt' (impasse), så hævder Badiou i modsætning til Lacan, at det reelle ikke blot unddrager sig, men at det er muligt at give det reelle en form for konsistens gennem formalisering: "Hvis, som Lacan siger, det reelle er formaliseringens dødvande [impasse] [...], så må vi hævde, at formalisering er det reelles i-gennemgang [im-passe]" Alain Badiou, Théorie du sujet (Paris: Seuil 1982), 41 (herefter TS).

12. LS, 157.

13. LS, 219 (original kursivering). 
Formalisering er således snarere en måde at participere i det reelle på. En handling, hvorigennem det reelle træffes og passerer. ${ }^{14}$

Den læsning, som Badiou praktiserer i Saint Paul, kan umiddelbart betegnes som formalisering $\mathrm{i}$ den forstand, at det, der interesserer $\mathrm{Ba}$ diou ved Paulus' breve, netop ikke er indholdet af det, der fremsættes i disse breve, altså kort sagt budskabet om Kristi død og opstandelse. Dette budskab udgør for Badiou en irrelevant fabel. Det, der interesserer Badiou, er alene den rent formale struktur i det, der fremsættes. Eller mere præcis de formale strukturer ved det sandhedsbegreb eller den teori om sandhed, som han mener udfoldes i Paulus' breve. I sin læsning af brevene, først og fremmest Romerbrevet og Galaterbrevet, inddrager Badiou en række centrale begreber fra sit hovedværk L'être et l'événement fra 1988 for at klarlægge Paulus' sandhedskonception. Begreber som 'begivenhed', 'begivenhedssted', 'situation', 'situationens tilstand', 'navngivning', 'intervention', og 'troskab'. Badiou benytter i L'être et l'événement dette begrebsapparatur til at udfolde en ny og dybt original sandheds- og subjektsteori, der har den moderne matematiks mængdelære som sin væsentligste inspirationskilde, og som endvidere kan udtrykkes i denne disciplins strengt formalistiske diskurs. Selvom det ikke udtrykkes eksplicit i Paulus-bogen, er det således nærliggende at hævde, at det sandhedsbegreb, som Badiou optegner konturerne af hos Paulus ved at genbeskrive dets formale betingelser gennem sit eget filosofiske begrebsapparatur, skal forstås som en formalisering af Paulus' sandhedskonception. En konception af sandheden, der, som vi skal se, ikke drejer sig om fortolkning og forståelse, men som gennem Badious begrebsapparatur netop formaliseres som en handling. Det vil, som Badiou udtrykker det i L'être et l'événement, sige, at "[...] sandheden er ikke et spørgsmål om kontemplation - eller immobil viden - men om intervention." 15 I forlængelse heraf synes det oplagt at spørge, om Badiou ligeledes kan siges at forstå Paulus' eget forehavende som en form for formalisering, et spørgsmål, jeg vil berøre ganske kort afslutningsvis.

Når Badiou afviser en hermeneutisk læsning af Paulus, så skal det også ses i forlængelse af et mere gennemgribende opgør i Badious for-

14. I det tidlige hovedværk Théorie du sujet fra 1982 understreger Badiou: "Vi har brug for en teori om det reelles passage i det område, der åbnes af formalisering. Her er det reelle ikke længere kun det, som kan være fraværende fra sit sted, men det, der passerer igennem ved forcering" (TS, 41). Badious teori om subjektet, der videreudvikles i L'être et l'événement, er præcis en sådan teori, idet subjektet her netop tænkes som det forceringspunkt, hvorigennem det $\mathrm{i}$ en given situation umulige bliver muligt: "Værens dødvande [...] er i sandhed subjektets passage" Alain Badiou, L'être et l'événement (Paris: Seuil 1988), 469 (herefter EE). Se endvidere EE, 429-470.

15. EE, 235. Se også SP, 16. 
fatterskab med den såkaldte 'sproglige vending', ${ }^{16}$ som han ser som et udtryk for den aktuelle filosofis historicistiske og relativistiske karakter (hvorfor han da også ofte betegner denne som 'sofisteri' snarere end egentlig filosofi). Set i 'fugleperspektiv', som Badiou udtrykker det, kan samtidens filosofi siges at være domineret af tre retninger, en tysk hermeneutisk retning, en angloamerikansk analytisk retning og en fransk postmoderne retning, som på trods af deres mange indbyrdes forskelligheder har det til fælles, at de har givet køb på et af filosofiens mest grundlæggende begreber, nemlig sandhedsbegrebet. ${ }^{17}$ Dette klassiske filosofiske begreb, hævder Badiou, afvises i dag konsekvent på tværs af filosofiske skel til fordel for et altovervejende fokus på sproget. Eller som han formulerer det i sin temmelig polemiske samtidsdiagnose i det første kapitel af Saint Paul: "Den progressive reduktion af sandhedsspørgsmålet (og dermed af tanken) til en form for sproglige domme, [er] et punkt, på hvilket både den anglo-saksiske analytiske ideologi og den hermeneutiske tradition er enige [...]."18 De fleste af samtidens filosoffer værger sig således imod sandheden med dens essentialistiske, og ikke mindst totalitære, konnotationer, for i stedet mere beskedent at nøjes med at tale om en mangfoldighed af historisk specifikke 'narrativer', 'betydningshorisonter', 'diskursregler' og 'sprogspil'. Denne afskedigelse eller udvanding af sandhedsbegrebet i den aktuelle filosofi kommer i Badious optik til udtryk på flere forskellige måder, men det væsentlige i denne sammenhæng er den forandring, begrebet undergår i den hermeneutiske tradition.

Mens Badiou uforbeholdent tilslutter sig hermeneutikkens opgør med det korrespondensteoretiske sandhedsbegreb og det erkendelsesteoretiske paradigme, der udgør dette begrebs forudsætning, så afviser han ligeså konsekvent hermeneutikkens sammenkædning af sandhed og mening som udtryk for en reduktion af sandhedsbegrebet. Hermed afviser han samtidig også implicit hermeneutikkens karakter af filosofi. Sammenkædningen af sandhed og mening udgør ifølge Badiou da også snarere essensen af religion: "Jeg kalder 'religion' alt

16. Se Alain Badiou, Infinite Thought - Truth and the Return to Philosophy (London: Continuum 2003) (hereafter IF), samt Alain Badiou, Conditions kapitel 1 og Alain Badiou, Manifeste pour la philosophie (Paris: Seuil 1989). Dette opgør kan imidlertid allerede spores i Théorie du sujet (TS, 204).

17. IF, 46. Dette har ifølge Badiou den konsekvens, at filosofien opgives i dens 'locus classicus', hvor sandhedsbegrebet er omdrejningspunkt, hvilket kommer til udtryk i den påstand om 'metafysikkens afslutning', der i varierende udgaver fremsættes af samtlige af disse tre filosofiske retninger. Den grundlæggende ambition i L'être et l'événement og efterfølgeren Logique des mondes. L'être et l'événement II fra 2006 er i modsætning hertil netop at vise, at filosofien stadig, eller måske rettere: igen er mulig.

18. SP, 7. 
det som forudsætter, at der er en kontinuitet mellem sandhed og cirkulationen af mening." 19 Med sin af-sløringsstruktur implicerer hermeneutikkens meningsbegreb - i lighed med kristendommens åbenbaringsbegreb - en dimension, der på én og samme tid er grundlæggende og unddragende, en bagvedliggende utilgængelighed, som for Badiou at se er uforenelig med modernitetens religionskritiske erklæring om Guds død og står i direkte modsætning til filosofiens egen afmytologiserende gestus.

Selvom religion sjældent er direkte genstand for overvejelse hos $\mathrm{Ba}-$ diou, så spiller den - ligesom filosofiens to rivaler 'sofisme' og 'antifilosofi' - en vis rolle som negativ afgrænsende instans i hans forsøg på at definere filosofi. Der hersker således helt klart et modsætningsforhold mellem religion og hermeneutik på den ene side og filosofi på den anden: "Filosofien adskiller sig fra religionen, fordi den adskiller sig fra hermeneutikken." 20 Badious anliggende med hermeneutikken kan derfor ikke blot reduceres til et metodologisk anliggende. Det handler snarere - med sandhedsbegrebet som omdrejningspunkt om grundlæggende kolliderende bestemmelser af, hvad filosofi (og religion) er. Det ses tydeligt i den følgende passage fra en tekst om Loius Althussers opfattelse af filosofi, der derfor også fortjener at blive citeret:

Inden for filosofien selv, afgrænser den [Althussers konception af filosofi] sig fra enhver hermeneutisk konception af filosofi. Dette er en ekstremt dyrebar arv. Ideen om filosofi som spørgen og åbenhed bereder, som vi ved, altid vejen for det religiøses tilbagevenden. Jeg benytter 'religion' her til at beskrive det aksiom, ifølge hvilket en sandhed altid er fange af hemmelighedens mening og et anliggende for interpretation og eksegese. [...] Althusser opretholder i filosofien, ligesom andre, såsom Lacan, gør det i antifilosofien, forudsætningen for radikal ateisme, der kan udtrykkes i én enkelt sætning: Sandhed har ingen mening. Heraf følger, at filosofi er en handling og ikke en fortolkning. ${ }^{21}$

På den baggrund kan man sige om Badious 'metode', at den bedst lader sig forstå som en filosofisk handling i den forstand, at den har karakter af en intervention snarere end en interpretation, men også i den forstand at hans formalistiske læsning af Paulus i en vis forstand udgør en del af en mere omfattende intervention i diskussionen (som

19. C, 80. Denne (noget brede) definition på religion er nogenlunde gennemgående i Badious senere værker.

20. C, 69. En sådan identifikation af religion og hermeneutik bekræftes i øvrigt, om end positivt valoriseret, af hermeneutikken selv. Se Gadamer 2004), 404 (For henvisningen tak til Carsten Pallesen).

21. Alain Badiou, Petit panthéon portative (Paris: La fabrique editions 2008), 67-68. 
altså også indirekte tematiserer spørgsmålet om religion) om, hvad filosofi er, ja i diskussionen om, om filosofien overhovedet længere er mulig. Bogen om Paulus er med andre ord i høj grad led i Badious egen særlige dagorden, og han afslutter da også prologen i Saint Paul med at understrege, at "Min intention er, helt klart, hverken historiserende eller eksegetisk. Den er helt igennem subjektiv." 22 Hvad der så mere præcist ligger i denne 'subjektive intention', og hvorledes den kommer til udfoldelse, det skal afklares i det resterende af artiklen.

\section{Badious brug af Paulus}

Jeg vil mene, at der kan peges på (mindst) tre forskellige forhold eller funktioner, når det gælder dette spørgsmål om Badious subjektive interesse i Paulus. De kunne fx tildeles følgende overskrifter: litterær eksemplifikation, filosofisk intervention og politisk inspiration. Lad os tage dem en ad gangen.

\section{Litterer eksemplifikation}

I Saint Paul benytter Badiou sig som nævnt ovenfor af et greb, der består i at bringe en række begreber fra L'être et l'événement i spil i sin læsning af Paulus' tekster, der hermed kommer til at fremstå i et ganske bestemt lys. Denne proces er selvfølgelig gensidig. Og Saint Paul benyttes da også flittigt i receptionslitteraturen til at belyse centrale elementer i Badious filosofi, som han oprindeligt udviklede i det noget mere krævende værk L'être et l'événement. Det rejser imidlertid spørgsmålet om, hvorvidt Badious Paulus-læsning ligefrem skal læses som en illustration og i så fald nærmere bestemt af hvad. Et bud kunne være at læse bogen som Badious eksemplificering af det, han kalder en 'sandhedsprocedure'. Det lægges der i hvert fald op til hos en række af Badious fortolkere. ${ }^{23}$ Hvad er så en 'sandhedsprocedure'? En sandhed opstår ifølge Badiou altid i forlængelse af en begivenhed, en uventet hændelse, som er forudsætningen for, at der i en given situation kan opstå noget nyt. Det nye, der bliver til i kølvandet på en begivenhed, er en sandhed. Sandheden er derfor heller ikke noget, der opnås gennem indsigt eller i form af viden, tværtimod bliver en

\section{SP, 2.}

23. Fx. følgende: Jean-Jacques Lecercle, "Cantor, Lacan, Mao, Beckett, meme combat - The Philosophy of Alain Badiou”, Radical Philosophy 93 (1999), 6-13; Slavoj Žižek, The Ticklish Subject (London: Verso 1999), 127-170; Simon Critchley, "Demanding Approval: On the Ethics of Alain Badiou", Radical Philosophy 100 (2000), 16-27. 
sandhed til gennem et brud med situationens etablerede viden, muliggjort af begivenhedens indbrud i situationen. Sandheden er i Badious optik at være tro imod en begivenhed, som når man på engelsk taler om at være true to, fx en sag eller en person. I den forstand er sandheden en proces, som indstiftes og alene opretholdes gennem de personer, der gennem deres intervention $\mathrm{i}$ en given situation bekendtgør, navngiver og udviser en fortsat troskab imod en begivenhed, og som Badiou derfor betegner som 'subjekt' for denne begivenhed. En 'sandhedsprocedure' er med andre ord den operation og proces, hvorigennem der $\mathrm{i}$ forlængelse af en begivenhed, som ifølge Badiou indtræffer på enten videnskabens, kunstens, politikkens eller kærlighedens domæne, skabes en sandhed og et subjekt for denne sandhed. ${ }^{24}$ Det synes umiddelbart oplagt at se Badious fremstilling af Paulus som en eksemplificering af en sådan 'sandhedsprocedure': I forlængelse af opstandelsen bekendtgør og navngiver Paulus en begivenhed, som han gennem sine breve opretholder en troskab imod og udfolder konsekvenserne af, hvorved der indstiftes et subjekt $\mathrm{i}$ form af den kristne menighed. Men i så fald bliver det lige så oplagt at spørge til, i hvilket domæne den kristne sandhedsprocedure hører hjemme. Er Paulus videnskabsmand, kunstner, politikere eller elsker? Eller er der, som bl.a. Slavoj Žižek har antydet, snarere tale om, at den sandhedsprocedure, som Saint Paul synes at eksemplificere, hører til $\mathrm{i}$ et hos Badiou uudtalt femte sandhedsdomæne, nemlig religionens? ${ }^{25}$ En sådan udlægning har Badiou dog selv kategorisk afvist:

Paul is not at all in the same field as my examples of truths in politics, art, science and love. Religion is simply not in the same field. There is something in my friend Slavoj's consideration that is not completely precise because the comparison is not between political revolutions, artistic creations, new theories of science, new experiences of love, and Paul. The comparison is between philosophy and Paul; that is, between my conception of truth and the Pauline conception of truth. So religion does not make a fifth on the list of politics, science, art and love. ${ }^{26}$

24. Jeg parafraserer her L'etre et l'événement, men Badiou præsenterer også selv lignende parafraser, bl.a. i Alain Badiou, Etikken - Et essay om erkendelsen af det onde (Århus: Philosophia 2007), 55-59 (herefter E).

25. Slavoj Žižek: “On Divine Self-Limitation and Revolutionary Love”, i Journal of Philosophy \& Scripture, 1:2 (2004), 32-38, 32.

26. UT, 40. Badiou er dog ikke helt uforskyldt i, at Saint Paul læses som en eksemplificering af en (femte) sandhedsprocedure, da han har valgt at benytte det ærke-paulinske ord 'nåde', når han i en række andre sammenhænge har skullet beskrive det forhold, at der indtræffer en begivenhed, på baggrund af hvilken vi får mulighed for at blive subjekter for en sandhed. 
Badious afvisning udelukker imidlertid ikke, at hans Paulus-læsning kan ses som en eksemplificering; der er bare ikke tale om en eksemplificering af en sandhedsprocedure, men af et bestemt sandhedsbegreb. ${ }^{27}$ Det er en betragtning, Badiou bekræfter i et andet interview, hvor han udtaler, at "Det, jeg viser, er, at Paulus' argumentation udelukkende er baseret på en opfattelse af sandheden, som forekommer mig i dens mest generelle aspekter at være helt acceptabel for mig som en filosof, der i dette tilfælde, og i mange andre, kan lære noget af antifilosoffen." 28 Det er således også særdeles nærliggende at se Badious læsning af Paulus' breve som en form for 'litterær' eksemplificering af hans egen sandheds- og subjektsteori. ${ }^{29}$

I konklusionen på Saint Paul lufter Badiou desuden et andet og mere kompliceret argument for, hvorfor Paulus ikke bør opfattes som et eksempel på det, han forstår ved en sandhedsprocedure. Argumentet går på, at fordi den begivenhed, som Paulus bekendtgør og er tro imod (altså opstandelsen) har karakter af en fabel, er det udelukket at betragte Paulus som en kunstner, en videnskabsmand, en elsker eller en politisk aktivist. ${ }^{30}$ Det, der altså også diskvalificerer Žižeks og andres postulat om, at kristendommen synes at udgøre en sandhed inden for rammerne af Badious egne kriterier, er, at den begivenhed, som kristendommen er forankret i, i Badious øjne ikke er en genuin begivenhed. Problemet er selvfølgelig, hvordan man så skelner dels en begivenhed fra en almindelig hændelse, dels en genuin begivenhed fra noget, der forgiver at være en begivenhed, men i virkeligheden ikke er det, altså en falsk begivenhed. I modsætning til en almindelig hændelse indtræffer en begivenhed ifølge Badiou altid uden grund, dvs. uden årsag og formål. Den lader sig derfor heller aldrig objektivt bestemme, ligesom den heller ikke kan forudsiges. En begivenhed viser sig derimod altid alene som begivenhed retrospektivt i form af en subjektiv bekendtgørelse af og troskab imod en bestemt begivenhed. ${ }^{31}$ På den-

27. Som Roland Boer overbevisende har demonstreret, findes der imidlertid 'belastende beviser' andetsteds i Badious værk, som peger i retning af, at Badiou, i det mindste på et tidligere tidspunkt i forfatterskabet, har anset religion for at udgøre et sandhedsdomæne på linie med kunst, politik, videnskab og kærlighed. Roland Boer, "The Fables of Alain Badiou", i Roland Boer, Criticism of Religion: On Marxism and Theology II (Leiden: Brill 2009), 155-179.

28. Alain Badiou, "Paul le Saint - interview par Jacques Henric", Art press 235 (1998), 53-58, 55.

29. Som sådan ligger Saint Paul i klar forlængelse af meditationen over Pascal i L'être et l'événement. (EE, 235-245).

30. SP, 116.

31. C, 199-200; EE, 193-204 + 223-234; E, 55-59. Badiou skelner mellem naturlige og historiske situationer, kun i de sidste kan der indtræffe begivenheder i Badious forstand (EE, 197). 
ne baggrund kan det umiddelbart være svært at se, hvorfor opstandelsen ikke kunne have karakter af en begivenhed. Men Badious kriterium for en genuin begivenhed har imidlertid ikke med begivenhedens karakter, men med dens effekter at gøre. Kort sagt er kriteriet nemlig, at hvis en begivenhed ikke er universelt adresseret, så er der ikke tale om en ægte, men en falsk begivenhed. I sin lille bog Etikken nævner Badiou nazismen som et eksempel på en falsk begivenhed. At der her er tale om en falsk begivenhed forklarer han således: "Det gribende brud, som nazisternes magtovertalelse i 1933 medførte, og som formalt ikke kan skelnes fra en begivenhed [...] henvender sig derimod, fordi det tænker sig selv som en 'tysk' revolution og kun er tro imod et folks antagne substans, i virkeligheden kun til dem, som den bestemmer som 'tyskere'." 22 Nazismen er ikke en ægte begivenhed, fordi den funderer sit brud med situationen, ikke i en universalitet, men netop i det tyske folks partikularitet. At begivenheden er en falsk begivenhed, betyder samtidig, at den sandhed og det subjekt, der bliver til i forlængelse heraf, ligeledes må afvises. Der er i Badious optik blot tale om et simulacrum. ${ }^{33}$ Men er opstandelsen så en pseudo-begivenhed? Er kristendommen et simulacrum? På den ene side må man indrømme, at selvom Badiou mig bekendt aldrig eksplicit har hævdet noget sådant, så er der bestemt forhold, der peger i den retning, som fx den følgende udtalelse: "Kristendommens historie har til fulde bevist, at den ikke havde karakter af en sandhed (i den betydning jeg giver ordet), men af statslig magt." 34 På den anden side ville det ikke stemme særlig godt overens med, at Badiou ikke blot i bogen om Paulus, men også ved en række andre lejligheder har fremhævet netop Paulus' budskabs universelle karakter. Således understreger han eksempelvis i et interview: "Som Paulus bekendtgør, hvis Kristus virkelig genopstod, så findes der ikke længere jøder eller græker, mænd eller kvinder, slaver og frie." 35 Men under alle omstændigheder er det væsentlige her det, at fordi Paulus' begivenhed ikke udgør en ægte begivenhed, så er der ifølge Badiou heller ikke tale om, at der med kristendommen er indstiftet en ny sandhed.

\section{Filosofisk intervention}

Det betyder imidlertid ikke, at Paulus' breve ikke er udtryk for noget nyt. Tværtimod, som undertitlen (La fondation de l'universalisme) på

32. E, 89. Se også Alain Badiou, Polemics (London: Verso 2006), 167-181 (herefter P).

33. E, 90.

34. Alain Badiou, "Paul le Saint - interview par Jacques Henric", Art press 235 (1998), 53-58, 55.

35. Ibid. Se også UT, 39; P, $108+162-63+236$. 
Badious bog antyder, ser Badiou faktisk Paulus som udtryk for et nybrud, nemlig intet mindre end universalismens grundlæggelse. Dette er en forholdsvis bombastisk påstand, som Badiou da også modererer og præciserer i bogens konklusion. Her indskærper han, at undertitlen ikke skal forstås således, at der ikke skulle have fandtes et begreb om universalisme, eller rettere universelle sandheder, før Paulus. Badious pointe er i stedet, at Paulus udgør et nybrud i dette begrebs historie. Paulus er den første til at rodfæste universalismen i en singulær begivenhed: Kristi opstandelse adresseret til hele menneskeheden. At denne begivenhed, opstandelsen, så slet ikke er en begivenhed betyder ifølge Badiou ikke noget for værdien af det, Paulus har at sige os: "At den begivenhed, han peger på, er en fabel [...], ugyldiggør på ingen måde den samling af ytringer, hvor Paulus anbringer sin opfattelse af, hvad en sandhed er." 36 Paulus er skelsættende, ikke fordi, der med ham indstiftes en ny videnskabelig, kunstnerisk, politisk eller kærlighedsmæssig sandhed, heller ikke fordi han grundlægger universalismen som sådan, men fordi hans breve rummer elementerne til det, Badiou kalder en ny teori om sandheden som 'universel singularitet', med andre ord en teori, der illustrerer de formale betingelser for den universelle sandhed og det singulære subjekt, der bliver til i forlængelse af begivenheden. Som Badiou siger i et interview: "I read Paul as a text about a new and provocative conception of truth and, more profoundly, about the general conditions for a new truth." 37 Men dette gør som sagt ikke Paulus selv til et sandhedssubjekt. Paulus er hverken videnskabsmand, kunstner, politikere eller elsker, han er 'sandhedsprocedurernes teoretiker'. For Badiou handler det om ved hjælp af sine egne filosofiske begreber at uddrage denne teori fra den mytologiske sammenhæng, som den er indlejret $i$, således at den kommer til at fremstå i en fuldstændig 'sekulariseret' form. ${ }^{38}$

Fordi Paulus' budskab er baseret på en fabel, udgør det ikke en sandhed, som vi stadig kan være tro imod på samme måde som Badiou fastholder, at vi stadig i dag kan (og bør) være tro imod de sandheder, der blev til på baggrund af genuine begivenheder som $\mathrm{fx}$ den franske revolution og 68-oprøret. Det Paulus ifølge Badiou kan tilby-

36. Ibid. Hermed afviser Badiou også, at det skulle være et problem, at det måske bedste eksempel på hans sandheds- og subjektsteori ikke selv udgør en sandhed, hvad Žižek ellers har fastholdt.

37. UT, 38 (original kursivering).

38. SP, 70. Det er et anliggende, Badiou kan siges at foregribe, om end udfoldet i en langt mindre grad, i meditationen fra L'etre et l'êvénement over Pascal, hvor han afslutningsvis (i modsætning til dem, der beklager, at Pascal spildte sit geni på kristendommens 'religiøse vrøvl') begrunder sin interesse for Pascal på følgende måde: "Det er alt for tydeligt for mig, at hinsides kristendommen, er det, der er på spil her [hos Pascal] sandhedens militante anordning [...].” (EE, 245). 
de er i stedet en teoretisk inspiration for filosofien til at gentænke sandhedsbegrebet. I Badious optik er det af afgørende betydning for filosofiens videre eksistens at fastholde og reformere dens centrale begreber, herunder sandhedsbegrebet. Med det som afsæt vil jeg mene, at Badious Paulus-læsning kan betragtes som en form for filosofisk intervention. Spørgsmålet er så, hvad det er filosofien nærmere bestemt kan lære af Paulus, når det gælder sandheden. På sin vis kan hele Saint Paul læses som et svar på netop dette spørgsmål, som Badiou forholder sig mere eksplicit til det i bogens konklusion. Her fremhæver han Paulus som en advarsel til filosoffen om ikke at forsøge at reducere betingelserne for sandhed til et rent begrebsligt anliggende, en advarsel, der gælder såvel sandhedens udgangspunkt som dens bestemmelse. ${ }^{39}$ Filosofien må forstå, at det handler om at begynde med en begivenhed, hvis den skal kunne tænke sandheden både i dens singularitet og universalitet som noget, der på en og samme tid gælder for alle, men uden hermed at være bundet til nogen form for transcendens. Hvad angår sandhedens bestemmelse, tilbyder Paulus ifølge Badiou filosofien følgende lektion: "Der er ingen myndighed, foran hvilken resultatet af en sandhedsprocedure kan stævnes. En sandhed er aldrig en sag for Kritikken. Den understøttes kun af sig selv og er korrelat til en ny type subjekt, hverken transcendentalt eller substantielt, men alene defineret som militant for den pågældende sandhed." 40 Filosofien må på én og sammen tid fastholde sandhedens universalitet og vedkende sig dens fordring om et radikalt engagement.

At tænke sandheden på en sådan måde er efter Badious mening $\mathrm{i}$ dag en yderst presserende opgave. Hvorfor? Det korte svar er: Fordi vores samtidssituation er karakteriseret ved en passiviserende relativering af sandheden. Vi befinder os $\mathrm{i}$ en situation, der efter Badious mening er domineret af en falsk universalisme i form af kapitalismens abstrakte homogenisering på den en side og en konstant eskalerende fragmentering $\mathrm{i}$ form af en identitetspolitisk partikuralisme på den anden side. Det er en situation, som relativerer og perverterer ikke bare politikkens, men alle de fire sandhedsdomæner og deres sandhedsprocedurer. Det er en situation, hvor kunst reduceres til kultur, videnskab til teknik, politik til management og kærlighed til sex,

\section{SP, 116.}

40. SP, 117. På såvel fransk som på engelsk betyder ordet 'militant' først og fremmest 'forkæmper' eller 'aktivist', og forbindes således ikke (som på dansk) hovedsagligt med bevæbning eller en voldelig adfærd, når jeg alligevel har valgt den ordrette oversættelse er det fordi 'militant' er et gennemgående begreb hos Badiou. Teologisk perspektiveret kan man sige, at ordet har nogenlunde sammen betydning som i formlen 'ecclesia militans' (lat.: den kæmpende kirke). 
hvorved enhver skabelse af universelle sandheder udelukkes. ${ }^{41}$ Netop $i$ en sådan situation, som er blottet for både engagement og universelle prætentioner, bør filosofien tage ved lære af Paulus' udformning af sandhedsbegrebet. Med Badious programmatiske formulering fra Saint Paul: "Skarpt at adskille hver sandhedsprocedure fra den 'kulturelle' historicitet, hvori offentlige mening antager at opløse den: det er operationen, hvori Paul er vores guide." Eller som han skriver, efter i fire maksimer at have skitseret de fordringer, der knytter sig til sandheden som universel singularitet, og som derfor dikterer Paulus' grundlæggende problematik: "Der er ikke en af disse maksimer, som, hvis man ser bort fra begivenhedens indhold, ikke kan tilpasses vores situation og vores filosofiske opgave." 42 Det er i denne forstand, at Badious Paulus-bog kan siges at udgøre en filosofisk intervention. En filosofisk intervention, der, som jeg allerede har antydet, altså ligeledes rummer en politisk dimension.

\section{Politisk inspiration}

Det bringer os til den sidste dimension af Badious subjektive interesse i Paulus, nemlig det, man kunne kalde den politiske inspiration. Skal kan tro en af Badious mest kompetente kommentatorer, Justin Clemens, er der nemlig en klar sammenhæng imellem Badious formalisering eller sekularisering af Paulus og så muligheden for at udlæse et politisk potentiale hos denne:

One must not underestimate this aspect of Badiou's work, which, having pure reason as a paradigm, induces him to repudiate all forms of religious and theological thought. This does not mean that he does not engage with examples of such thought. On the contrary, he makes committed intervention into such thought, by essaying to detach what he de facto treats as the pure thought of such thinkers from the 'religious' impurities in which they have become enmired. In this approach, somebody like Saint Paul becomes an exemplary political militant and thinker, who ought to be extracted from his religious envelop, including from the history of the church. ${ }^{43}$

En række kommentatorer har argumenteret for, at den politiske dimension ved Badious Paulus-bog bedst lader sig forstå ved at indskri-

41. Se også Etikken for en uddybende beskrivelse af den samtidige situation, hvor man ifølge Badiou har opgivet universalismetanken til fordel for en hyklerisk 'respekt for forskellighed' (E, 39).

42. SP, $7+16$.

43. Justin Clemens, "Had we but worlds enough, and time, this absolute, philosopher...”, Paul Aston, A.J. Barlett \& Justin Clemens (eds.), The Praxis of Alain Badiou (Melbourne: re.press 2006), 102-143, 116. 
ve den i den omfattende marxistiske tradition fra Friedrich Engels og Karl Kautsky over Ernst Bloch og Walter Benjamin til Frederic Jameson og Terry Eagleton, for at trække paralleller imellem marxismens og kristendommens 'revolutionære' aspekter (som regel i form af en fælles utopisk/eskatologisk dimension). ${ }^{44}$ Det, der gør Paulus politisk i Clemens' præsentation af Badious læsning, er imidlertid ikke det religiøse eller teologiske aspekt. Tværtimod, pointen synes netop at være, at Paulus først bliver politisk, i det øjeblik hans breve gennem Badious læsning renses for deres teologisk-religiøse tankegods. Clemens' kommentar rejser således et særdeles interessant spørgsmål: Hvis Saint Paul kan ses som et udtryk for, at Badiou mener, at Paulus rummer en ressource til politisk fornyelse i den aktuelle situation, hvor marxismen synes at være i dyb krise, hvordan skal det så nærmere forstås? Er det ensbetydende med, at Badiou hermed positivt tilslutter sig den føromtalte idé om, at der eksisterer en nær forbindelse imellem kristendom og marxisme? Eller ligger der i Badious læsning af Paulus snarere ligefrem et opgør, ikke blot, som vi allerede har set antydet, med religionen, men ligeledes med den marxistiske tradition? Disse spørgsmål er selvsagt væsentlige for forståelsen, ikke blot af Badious (politiske) interesse i Paulus, men ligeledes af hans opfattelse af forholdet mellem religion og politik.

Der er næppe tvivl om, at der hersker en udbredt opfattelse af, at Badiou sammen med en række andre marxistisk-inspirerede tænkere, først og fremmest Giorgio Agamben og Slavoj Žižek, skal ses som det nyeste skud på stammen i en tradition af 'kristendomssympatiske' marxister. En sådan læsning er også blevet forstærket af bestemte omstændigheder i receptionen af Saint Paul og måske særligt via Žižeks rolle i denne reception. For selvom Žižek åbenlyst, og indirekte gennem sine referencer, gerne vedstår inspirationen fra Saint Paul i de bøger, hvor han selv behandler teologiske temaer, så er der en tendens til, at det alligevel er Badiou, der læses i forlængelses af Žižek (som har en stor aktie i den voksende interesse for Badious værk) snarere end omvendt. ${ }^{45}$ Der er ingen tvivl om, hvor Žižek mener, Badiou står i spørgsmålet om forholdet mellem marxisme og kristen-

44. For en imponerende kortlægning af Bibelens og den kristne traditions rolle i det 20. århundredes marxisme se Roland Boer, Criticism of Heaven: On Marxism and Theology (Leiden: Brill 2007) og Criticism of Religion: On Marxism and Theology II (Leiden: Brill 2009). Også teologer som Jürgen Moltmann, Johan Baptist Metz samt en række skikkelser inden for den latinamerikanske 'befrielsesteologi', har betonet sådanne paralleller.

45. Det skyldes formodentlig, at Badious bog først blev oversat til engelsk i 2003, dvs. efter samtlige Žižeks 'teologiske' udgivelser, men også, at Žižek, og herunder Žižeks læsning af Badiou, fortsat læses i langt bredere kredse end Badiou. 
dom. Det fremgår helt tydeligt af den følgende kommentar til marxismens traditionelt apologetiske attitude over for de velkendte beskyldninger om, at kommunismen blot udgør en sekulariseret religiøs sekt: "Following Alain Badiou's path-breaking book on Saint Paul our premise here is exactly the opposite one: instead of adopting such a defensive stance, allowing the enemy define the terrain of the struggle, what one should do is to reverse the strategy by fully endorsing what one is accused of; yes, there is a direct lineage from Christianity and Marxism [...]." 46 Der synes umiddelbart også at være godt belæg for Žižeks læsning hos Badiou selv. Ikke alene henvises der til både Marx, Lenin og Mao i Saint Paul, men Badiou benytter sig desuden flere gange i løbet af bogen af en klassisk marxistisk retorik, især i sin karakteristik af Paulus' person og virksomhed i bogens andet kapitel, som $\mathrm{fx}$ når han taler om kirken som 'partiet', eller om brødre som 'kammerater'. Paulus beskrives således som en stålsat leder, der gennem sit personlige engagement og sine skriftlige interventioner organiserede en politisk fraktion. ${ }^{47}$ Det er en beskrivelse, der harmonerer meget fint med Badious paralleller mellem Paulus og Lenin. ${ }^{48}$

Hvad angår det marxistiske vokabular, benytter Badiou først og fremmest dette i forbindelse med sine beskrivelser af Paulus som organisator, og sammenstillingen af Paulus og marxismen går da også netop på et organisatorisk fællestræk eller rettere et fælles organisatorisk problem. Dette problem består i, hvordan et sandhedssubjekt på den ene side organiseres således, at dets aktive troskab imod en begivenhed kan fastholdes, men på den anden side undgår, at den selv samme organisering fører til en dogmatisk, statisk, passiv troskab, og dermed en substantialisering af sandheden, som fx skete i det 20. århundredes kommunistiske partier (eller den katolske kirke). Sammenstillingen mellem Paulus og marxismen har altså ikke til formål at fremhæve et fælles revolutionært potentiale (i form af en fælles utopisk-eskatologisk dimension), som om marxismen skulle have glemt dette, men handler om at antyde en alternativ (politisk) organiseringsform. Dette organisatoriske problem er imidlertid ikke det primære anliggende for Badiou i Paulus-bogen; han er i sin læsning, som vi allerede har set, først og fremmest interesseret i Paulus som 'sandhedsteoretiker'. ${ }^{49}$

Det er da også i forlængelse af sandhedstematikken, at man skal forstå ordet 'militant', som Badiou benytter flittigt i Saint Paul. Umiddelbart er det nærliggende at forstå 'militant' synonymt med en

46. Slavoj Žižek, The Fragile Absolute: or why the Christian legacy is worth fighting for? (London: Verso 2000), 2.

47. SP, $21-22$

48. SP, $2+33$.

49. SP, 40. 
politisk aktivist, dvs. som en betegnelse for et politisk 'subjekt' i Badious forstand. En sådan udlægning er imidlertid med til at understøtte opfattelsen af, at Badious hovedanliggende med at læse Paulus skulle være politisk inspiration, altså tesen om, at Paulus udgør en vigtig politisk ressource for Badiou. Herfra er der ikke er særlig langt til at indlemme ham i kredsen af andre samtidige marxistiske filosoffer og intellektuelle, der priser kristendommen for dens revolutionære potentiale. Det skal naturligvis på ingen måde benægtes, at Badiou bruger ordet 'militant' som en betegnelse for det, han forstår ved et politisk subjekt. Men som det også fremgår af den følgende passage fra forordet til den engelske oversættelse af L'etre et l'événement, anvender Badiou ordet 'militant' som en generel betegnelse for det, han kalder sandhedssubjekter $\mathrm{i}$ samtlige af de fire sandhedsdomæner: "The militant of truth is not only the political militant working for the emancipation of humanity in its entirety. He or she is also the artist-creator, the scientist who opens up a new theoretical field or the lover whose world is enchanted." 50 Kort sagt, at være 'militant' har ikke nødvendigvis noget at gøre med at være politisk engageret, men med at være subjekt for en sandhed.

Parallellen i Saint Paul mellem de to militante figurer, Lenin og Paulus, er ikke et nyt indfald fra Badious side, men har et fortilfælde $i$ Théorie du sujet fra 1982. Her sammenligner Badiou eksplicit kristendommen og marxismen, men den sammenligning han drager, går ikke på et formodet fælles revolutionært eller utopisk aspekt; i stedet går den på et særligt træk ved de to bevægelsers tilblivelse. Begge bevægelser, kristendommen og marxismen, er nemlig ifølge Badiou kendetegnet ved at have en 'dobbelt begyndelse'. Marxismen begyndte med Marx, men det var først med Lenins organisering af partiet, at der indstiftes et egentlig marxistisk subjekt. På samme måde med kristendommen, som begyndte med Kristus, men først med Paulus blev organiseret som kirke. ${ }^{11}$ Uden dog at henvise eksplicit til Badiou genoptager Žižek (i en kommentar til Lenins skrifter) denne parallel på en interessant måde, der tillader os at vende tilbage til spørgsmålet

50. Alan Badiou, Being and Event (London: Continuum 2006), xiii. Som passagen antyder, har Badiou tidligere forbeholdt ordet 'militant' for det politiske subjekt af den simple grund, at han så sent som i Théorie du sujet var af den opfattelse, at "Ethvert subjekt er politisk. Det er derfor, der er så få subjekter og sjældent nogen politik" (TS, 46). I forlængelse af den begrebsramme, der udvikles i L'etre et l'événement og Manifeste pour la philosophie, udvider Badiou brugen af ordet 'subjekt', og hermed også betegnelsen militant, til at gælde alle fire sandhedsområder $(\mathrm{C}, 234)$.

51. TS, 143 . 
om, hvorvidt også Paulus' breve kan forstås som en form for formalisering. Žižek skriver:

We should introduce the key dialectical distinction between the founding figure of a movement and the later figure who formalized this movement: Lenin did not just adequately translate Marxist theory into practice - rather he 'formalized' Marx by way of defining the Party as the political form of its historical intervention - just as St. Paul 'formalized' Christ and Lacan 'formalized' Freud. 52

Med andre ord udgør Paulus altså en formalisering i den forstand, at kirken udgør formen af den intervention, Paulus iværksætter i forlængelse af Kristus. Om Badiou også forstår Paulus' breve som en form for formalisering som Žižek tydeligvis gør, er ikke helt så klart. Badiou benytter ikke ordet 'formalisering', en eneste gang i Saint Paul, men han kommer tæt på. Bl.a. beskriver han Paulus' breve som en reduktion, idet 'alt reduceres til et eneste punkt: Jesus, Guds søn, døde på korset og genopstod'; og som en 'kraftfuld ekstraktion af en tankes essentielle kerne'. I samme tekststykke konkluderer han: "Resultatet af alt dette er, at Paulus' breve er de eneste sande doktrinare tekster i Det Nye Testamente." 53 Det er en sætning, som det i denne sammenhæng er svært at undlade at læse i forlængelse af Badious beskrivelse af hans egen formaliserede sandhedsteori som en 'sandhedsdoktrin' ${ }^{54}$ Under alle omstændigheder gælder det, at Badious sammenstilling af Lenin og Paulus, marxismen og kristendommen, tydeligvis ikke drejer sig om et emancipatorisk eller revolutionært fællestræk, men igen snarere om en organisatorisk parallel.

Til trods for dette fælles organisatoriske anliggende er der imidlertid noget, der tyder på, at Badiou mener, at der i virkeligheden er langt mere, der skiller marxismen og kristendommen, end forener dem. Eksempelvis udtaler han sig på følgende vis om forholdet mellem religion og marxisme, eller rettere kommunisme, i et interview fra 2007: "In this case, religion presents itself as the surrogate for something else that has not been found, something that should be universalizable, should be able to uproot itself from the particularity of the religious. It is for this reason, I think, that Marx still seems so current. Communism, according to Marx, is essentially internationa-

52. Slavoj Žižek, “Afterword: Lenin's choice”,i Vladimir Il'ich Lenin, Revolution at the gates: a selection of writings from February to October 1917 (London: Verso 2002), 167-337, 191.

53. SP, 35.

54. Alain Badiou, "On a finally objectless subject”, Topoi 7 (1988), 93-98, 94. 
list in character." 55 Religion, herunder også kristendommen (i hvert fald sådan som den har udviklet sig efter Paulus), og marxisme/kommunisme er i Badious optik åbenlyst ikke positivt relateret (i kraft af et fælles revolutionært aspekt). Tværtimod står de - og her følger Badiou Marx - i modsætning til hinanden, idet religionen er en efterligning af eller erstatning for den ægte vare, nemlig kommunismen. Den afgørende forskel er her, at mens religion, i hvert fald i praksis, altid er bundet til en partikularisme, så har kommunismen efter Badious opfattelse en sandt universalistisk karakter. Hvis Badiou ellers kan siges at være enig med Žižek i, at Paulus repræsenterer en universalistisk arv, som fortsat er værd at kæmpe for, så synes han i modsætning til Žižek, der forbinder denne arv med kristendommen, at indtage en noget mere tvetydig position i forhold til denne forbindelse mellem kristendom og universalisme. På den ene side henviser Badiou gerne til Galaterbrevet 3,28 som et eksempel på en universalistisk tankegang, på den anden side er det altså ikke kristendommen, men snarere den trans-historiske figuration, som Badiou benævner 'invariant kommunisme', en figuration strækker sig fra Spartacus over Thomas Müntzer til Saint-Just, som han tilskriver universalismen, og som derfor udgør den arv, som det for Badiou er værd af kæmpe for. ${ }^{56}$ Den åbenlyse selvmodsigelse, der består i på den en side at henvise til Paulus som repræsentant for universalisme og på den anden at afvise religionen, herunder kristendommen, pga. dens partikularisme, lader sig kun opløse, hvis vi tager Badiou på ordet, når han nægter at forbinde Paulus med religion. Sat på (det yderste af) spidsen kan man sige, at det virkelig provokerende ved Badious læsning af Paulus ikke er, at han antyder, at kristendommens grundlægger er kommunist, men at han hævder, at kommunisten Paulus slet ikke er religiøs.

Hermed har Badiou om ikke andet så indirekte også signaleret, hvor han står i det normative spørgsmål om forholdet mellem religion og politik. Men lad os alligevel afslutningsvis citere hans svar fra et nyligt interview i Libération på spørgsmålet om, hvorvidt han mener, at der bør være en nær relation mellem religion og politik: "Min

55. Alain Badiou, “'We Need a Popular Discipline': Contemporary Politics and the Crisis of the Negative - Alain Badiou Interview by Filippo Del Lucchese and Jason Smith", Critical Inquiry 34 (2008), 645-659, 655.

56. Se Alain Badiou \& Francois Barmès, De lídéologie (Francois Maspero: Paris 1976), 60-75; Alan Badiou, De quoi Sarkozy est-il le nom? (Paris: Nouvelles Editions Lignes 2007) (kapitel 8-9). Badiou og hans medforfatter Balmès nævner i pamfletten De l'idéologie fra 1976 Thomas Müntzer og det tyske bondeoprør som et eksempel på det, de kalder en 'invariant kommunisme'. Det er imidlertid tydeligt, at når Müntzer indlemmes i denne kategori, er det ikke så meget på grund af hans kristne tilhørsforhold, men snarere på trods af det. 
holdning til dette spørgsmål, forstærket af en nylig rejse til Palæstina, er, at i dag er det bydende nødvendigt at skille politik fra religion, ligesom det bør være adskilt, for eksempel fra race- eller identitetsspørgsmål." 57 På baggrund ikke blot af denne ret utvetydige udmelding, men også af diskussionen ovenfor af hans opfattelse af forholdet mellem marxisme og kristendom, er der altså ikke meget, der tyder på, at Badiou ser et positivt politisk potentiale hverken i den kristne tradition eller i religionen som sådan. Tværtimod.

\section{Konklusion}

Jeg har i denne artikel forsøgt at afklare tre sammenhængende forhold ved Alain Badious bog om Paulus. For det først har jeg set nærmere på den uekspliciterede fremgangsmåde, der kendetegner Badious tilgang til Paulus' breve. Jeg har her argumenteret for, at hans læsning af Paulus kan karakteriseres som formalistisk i modsætning til en hermeneutisk tilgang, og at denne modstilling skal forstås på baggrund af et generelt opgør $\mathrm{i}$ hans forfatterskab med den såkaldte sproglige vending i filosofien, herunder især den hermeneutiske traditions begreb om mening. Denne diskussion af Badious fremgangsmåde fører til en mere overordnet diskussion af konkurrerende begreber om, hvad filosofi og i forbindelse hermed religion er eller bør være. For det andet har jeg forsøgt at belyse, hvordan vi nærmere skal forstå Badious tilkendegivelse i Saint Paul af, at hans anliggende eller intention i bogen 'hverken er historiserende eller eksegetisk, men helt igennem subjektiv'. Jeg har argumenteret for, at dette 'subjektive' anliggende kan indkredses via tre mere eller mindre sammenhængende aspekter eller dimensioner, som kan opsummeres under de følgende overskrifter: 'litterær eksemplifikation', 'filosofisk intervention' og 'politisk inspiration'. Omdrejningspunktet i alle tre dimensioner er det samme, nemlig Badious interesse i den teori eller konception af sandheden, som han mener at finde hos Paulus. Det er en sandhedskonception, der (måske) kan fungere som en intervenerende illustration af Badious egen sandhedsteori. Sidst, men ikke mindst, har jeg givet et fingerpeg om Badious position i forhold til de indledningsvis nævnte tre tematikker, der kendetegner den aktuelle tese om teologiens og religionens tilbagevenden i filosofien. Her mener jeg, at der er godt belæg for at konkludere, at Badious bog om Paulus og hans

57. "C'est le communisme qui est une idée neuve en Europe" - interview par Alain Badiou, Libération 26-01-2009 http://www.liberation.fr/politiques/120186-dialoguez-avec-alain-badiou 
værk mere generelt ikke bør læses som en del af en sådan vending. Badious filosofi er hverken postmetafysisk eller postsekulær, ligesom der heller ikke synes at være belæg for at hævde med Žižek, at Badiou rent faktisk mener, at 'der er et direkte slægtskab mellem kristendommen og marxismen'. 